DOI - 10.21707/gs.v10.n02a04

\title{
EFFECTS OF SITE PREPARATION ON PHYSICAL AND CHEMICAL PROPERTIES AS INDICATORS OF FOREST SOIL QUALITY
}

\author{
Felícia Fonseca ${ }^{1} \&$ Tomás de Figueiredo
}

${ }^{1}$ Centro de Investigação de Montanha (CIMO), Escola Superior Agrária de Bragança, Campus de Sta Apolónia, Apartado 1172, $5301-855$ Bragança, Portugal - Phone: (+351) 273 303 200, Fax:(+351) 273325 405,E-mail address:ffonseca@ipb.pt

\section{Recebido em 10 de novembro de 2015. Aceito em 04 de agosto de 2016. Publicado em 09 de dezembro de 2016.}

\begin{abstract}
Soil quality evaluation is an important tool to observe the sustainability of soil management practices. Therefore, an evaluation methodology was applied to seven sets of site preparation operations for forest stand installation (treatments), in order to assess their impacts on soil quality parameters. Treatments considered were (ranked from lowest to highest tillage intensity): (1) Original soil control (no intervention on the original abandoned field) (TSMO); (2) No subsoiling, no ploughing, plantation with hole digger (SMPC); (3) Subsoiling over the whole area, with covering shovel; (RCAV); (4) No subsoiling, contour bunds shaped by two plough passes (SRVC); (5) Subsoiling in future plantation rows, contour bunds shaped by two plough passes (RLVC); (6) Subsoiling over the whole area, contour bunds shaped by two plough passes (RCVC); (7) Subsoiling over the whole area, contour ploughing over the whole area (RCLC). These were applied in an experimental site near Macedo de Cavaleiros, NE Portugal, covering $1125 \mathrm{~m} 2$ each, further planted with a mixed stand (Douglas fir, Pseudotsuga mensiezii, and Chestnut, Castanea sativa). In each one of the treatments, 6 soil profiles were observed and sampled in the plantation row of the newly installed forest stand. Soil quality evaluation was done taking into account soil morphology features, soil analyses results at 0-20, 20-40 and 40-60 cm depth, and enrichment ratios of soil parameters computed with data of actual and undisturbed conditions. The treatments SRVC, RLVC and RCLC showed the highest depth with an increasing of 20 to $40 \mathrm{~cm}$ when compared with the original situation. Also the same treatments presented the highest values of carbon and nitrogen in the layer $20-40 \mathrm{~cm}$, but the lowest in the surface soil layer. Generally, no significant differences were found among treatments in what concerns exchangeable bases and acidity, cation exchange capacity, base saturation and $\mathrm{pH}$ values. The amounts of finer particles tend to increase with tillage intensity and, on the contrary, the opposite trend was found for bulk density. For the studied conditions, the SRVC and RLVC treatments seem to be the most adequate set of site preparation operations for new plantations of forest stands.
\end{abstract}

Key Words: Site PREPARATION, Forest STANDS, SOIL PROPERTIES, PortugaL.

\section{EFEITOS DA PREPARAÇÃo DO LOCAL SOBRE PROPRIEDADES FÍSICAS E QUÍMICAS COMO INDICADORES DA QUALIDADE DO SOLO DA FLORESTA}

Resumo - A avaliação da qualidade do solo constitui uma importante ferramenta para observação da sustentabilidade das práticas de manejo do solo. Nesse sentido, aplicou-se uma metodologia de avaliação a sete modalidades de preparação do terreno (tratamentos) com diferentes intensidades (ligeira, intermédia e intensiva), para observação dos impactes sobre parâmetros qualitativos do solo. Os tratamentos considerados foram: (1) testemunha, sem mobilização (TSMO); (2) plantação à cova, com broca rotativa (SMPC); (3) ripagem contínua, seguida de lavoura localizada com riper equipado com aivequilhos (RCAV); (4) sem ripagem e armação do terreno em vala e cômoro (SRVC); (5) ripagem localizada e armação do terreno em vala e cômoro (RLVC); (6) ripagem contínua e armação do terreno em vala e cômoro (RCVC); (7) ripagem contínua seguida de lavoura contínua (RCLC). Em cada tratamento com armação do terreno em vala e cômoro (SRVC, RLVC, RCVC), foram observados 12 perfis do solo (4 na linha de plantação, 4 na entre linha, 4 no cômoro). Nos restantes tratamentos, dada a homogeneidade das parcelas, foram observados 4 perfis por tratamento. A avaliação da qualidade do solo foi realizada com base nas características morfológicas dos perfis de solos por observação no campo e nos resultados analíticos de amostras de solo colhidas nos mesmos, nas profundidades 0-20; 20-40 e 40-60 cm. Os tratamentos SRVC, RLVC e RCLC apresentam espessura efectiva mais elevada tendo havido um acréscimo entre 30 a $40 \mathrm{~cm}$ relativamente à situação original. Igualmente apresentam os maiores teores de carbono e azoto totais na camada 20-40 cm e os menores na camada mineral superficial. De um modo geral, não ocorrem diferenças significativas entre tratamentos para as bases de troca, capacidade de troca catiónica, acidez de troca e grau de saturação em bases, bem como nos valores de $\mathrm{pH}$. A percentagem das partículas de granulometria mais fina tende a aumentar com a intensidade de mobilização do solo, verificando-se comportamento inverso para a massa volúmica e resistência do solo à penetração. Nas condições do estudo, os tratamentos SRVC e RLVC mostraram ser as técnicas de preparação do terreno mais sustentáveis na instalação de povoamentos florestais.

Palavras-Chave: Preparação do terreno, Povoamentos florestals, Propriedades do solo, Portugal.

\section{EFECTOS DE LA PREPARACIÓN DEL SITIO SOBRE LAS PROPIEDADES FÍSICAS Y QUÍMICAS COMO INDICADORES DE LA CALIDAD DEL SUELO FORESTAL}

Resumen - La evaluación de la calidad del suelo es una herramienta importante para observar la sostenibilidad de las prácticas de manejo del suelo. En este sentido, se aplicó una metodología de evaluación de siete métodos de preparación de la tierra (tratamientos) con diferentes intensidades (leve, intermedio y intensivo), para observar los impactos sobre los parámetros cualitativos del suelo. Se consideraron los tratamientos: (1) control, sin labranza (TSMO); (2) plantación de la fosa, taladro rotativo (SMPC); (3) subsolado en toda la zona (RCAV); (4) sin subsolado seguido de zanja y montículo (SRVC); (5) subsolado en la zona de zanja y montículo (RLVC); (6) subsolado en toda la zona seguido de zanja y montículo (RCVC); (7) subsolado en toda la zona seguido por labranza continuo (RCLC). En cada tratamiento con zanja y montículo (SRVC, RLVC, RCVC) se observaron 12 perfiles de suelos (4 en la línea de siembra, 4 entre la línea, 4 en el montículo). En los otros tratamientos, dada la homogeneidad de las parcelas se observó en 4 perfiles por tratamiento. Evaluación de la calidad del suelo se basa en las características morfológicas de observación mediante perfiles de suelo en el campo y los resultados analíticos de las muestras de suelo tomadas en ellas, en las profundidades 0-20; 20-40 y 40-60 cm. Los tratamientos SRVC RLVC y RCLC tienen mayor espesor efectivo de haber sido aumentado de 30 a $40 \mathrm{~cm}$ en comparación con la situación original. También tienen el más alto contenido de carbono y nitrógeno total en la capa de $20-40$ cm y más pequeños en la capa mineral superficie. En general, no hay diferencias significativas entre tratamientos para el intercambio de bases, capacidad de intercambio catiónico, acidez de cambio y el grado de saturación de bases, así como los valores de $\mathrm{pH}$. El porcentaje de partículas de tamaño de partícula más fino tiende a aumentar con la intensidad de la labranza, verificando el comportamiento opuesto a la resistencia a la penetración densidad y el suelo. Bajo las condiciones del estudio, los tratamientos SRVC y RLVC mostraron ser las técnicas de preparación de suelo más sostenible en la instalación de los rodales. Palabras Clave: Labranza, Rodales, Propriedades del suelo, Portugal.

\section{INTRODUCTION}

Forest soils in the Mediterranean region frequently have limited rooting depth, high coarse elements and low organic matter content, which tend to limit water storage in the soil profile. Accordingly, application of site preparation techniques is essential to enhance soil water storage and availability in these environments (Querejeta et al. 2001; Alcázar et al. 2002; Piatek et al. 2003; Imaz et al. 2010). However, site preparation for afforestation currently lacks accurate planning, based on sound 
experimental results driving to techniques most adequate to each situation and respecting stand productivity and ecosystem sustainability requirements. Improving soil quality is one of the most important factors for sustaining the global biosphere and fundamental in forest systems sustainability (Wang and Gong 1998). A simple set of established soil properties can provide useful information on soil quality (Sparling et al. 2004). Soil quality has been defined as "the capacity of a soil to function within ecosystem boundaries to sustain biological productivity, maintain environmental quality, and promote plant and animal health" (Doran and Parkin 1994). Land use and management practices seriously impact the direction and degree of soil quality changes in time and space (Wang and Gong 1998). Possibly the most significant impact of site preparation from a soil quality perspective is on rooting depth and soil hydrological processes, because increase the availability of resources that plants have access (water and nutrients). Runoff and sediment loss is commonly highest in the first few years after site preparation, for the reason that canopy cover is scarce and ground vegetation may be insufficient for controlling erosion (Lucci and Della Lena 1994; Figueiredo et al. 2011).

Taking in account the soil complexity and the high number of properties that can be monitoring, it is important to select the most appropriate to the objectives of soil management practices. For comparison different site preparation techniques (Schoenholtz et al. 2000) suggested as soil quality indicators, soil effective thickness, bulk density, soil penetration resistance, particle size, aggregate stability, organic matter content, nutrient availability, cation exchange capacity (CEC), base saturation (BS) and $\mathrm{pH}$, because these variables are generally sensitive to soil management practices. Due to inappropriate land use and management, soil erosion, acidification, nutrient depletion, pollution and other natural resource problems have been affected human development (Lal 1990; Figueiredo et al. 2011).

The objectives for this study were (i) evaluate changes in physical and chemical properties as indicators of forest soil quality, owing to mechanical site preparation; (ii) to compare soil quality using well-known indicators for that forest systems such as rooting depth, bulk density, particle size and nutrients availability; (iii) based on soil quality and productivity to indicate which techniques are most appropriate for the region under study.

\section{Materials AND Methods}

This study is a part of a large project, where were tested several site preparation operations in the environmental impacts (soil erosion and carbon storage), behavior of forest species installed (mortality, height and diameter growth, biomass production) and evolution of soil properties. Details of the design of this experiment are available in another published works (Fonseca et al. 2011; Figueiredo et al. 2011). Accordingly, only a succinct review is presented here.

The experimental field was established near Macedo de Cavaleiros, Northeast Portugal at $41^{\circ} 35^{\prime} \mathrm{N}$ and $6^{\circ} 57^{\prime} \mathrm{W}, 660$ to $701 \mathrm{~m}$ altitude, mean annual temperature $12^{\circ} \mathrm{C}$, mean annual rainfall $656 \mathrm{~mm}$, with a typically Mediterranean seasonal distribution (INMG, 1991). According to FAO/UNESCO (1988), soils are dystric Cambisols and dystrict Leptosols developed on schist, in the area characterized as sandy-loam, with high stoniness, normally acid, moderate to poor in organic matter content, with low to very low $\mathrm{P}$ and low to moderate $\mathrm{K}$ contents (Agroconsultores e Coba 1991; Fonseca 2005).

Experimental design comprised three blocks, where six treatments representing different intensities of soil disturbance by mechanical operations for site preparation, were randomly distributed on experimental plots (Table 1). This table includes also a treatment without disturbance (TSMO), which corresponds to the original soil and is taken as a reference for comparison with the remainder treatments in what concerns the tillage effects on chemical and physical soil properties. Site preparation techniques under test were selected among a set of commonly applied in afforestation schemes, yet with no consistent experimental base for such options.

Table 1 - Treatments related to six soil preparation operations before plantation

\begin{tabular}{|c|c|}
\hline Treatment & Description of site-preparation operations \\
\hline \multirow[t]{2}{*}{ TSMO } & Without disturbance (original condition) \\
\hline & Slight disturbance \\
\hline SMPC & No tillage and hole plantation with hole digger $(60 \mathrm{~cm}$ depth $)$ \\
\hline \multirow[t]{2}{*}{ RCAV } & Continuous subsoiling, using a covering shovel and plantation in the furrow (around $60 \mathrm{~cm}$ depth) \\
\hline & Moderate disturbance \\
\hline SRVC & $\begin{array}{l}\text { No previous subsoiling with furrow hillock surface soil with two plough passes and plantation in the } \\
\text { hillock side (around } 90 \mathrm{~cm} \text { depth) }\end{array}$ \\
\hline \multirow[t]{2}{*}{ RLVC } & $\begin{array}{l}\text { Subsoiling on planting row, followed by two plough passes, leaving furrow hillock surface soil and plan- } \\
\text { tation in the hillock side (around } 90 \mathrm{~cm} \text { depth) }\end{array}$ \\
\hline & High disturbance \\
\hline $\mathrm{RCVC}$ & $\begin{array}{l}\text { Continuous subsoiling, followed by two plough passes, leaving furrow hillock surface soil and plantation } \\
\text { in the hillock side (around } 90 \mathrm{~cm} \text { depth) }\end{array}$ \\
\hline RCLC & $\begin{array}{l}\text { Continuous subsoiling followed by continuous ploughing and plantation in the furrow (around } 90 \mathrm{~cm} \\
\text { depth), }\end{array}$ \\
\hline
\end{tabular}


The species selected were Pseudotsuga menziesii $(P M)$ and Castanea sativa (CS), which were planted at a distance of $4 \times 2$ $\mathrm{m}$ in alternate rows, with two rows for each plot, 12 plants in each row with a total of 24 plants per species. The plantation was made by hand, in February 2002, using nursery seedlings, $P M$ in plastic bags and $C S$ of bare root.

Before site preparation operations 48 soil profiles were observed, and one year after planting 6 soil profiles per treatment were observed in the plantation line. Soil samples were taken at 0-20, 20-40 and 40-60 to assess the effects of site preparation on soil properties and possible relationships with plant response. Soil quality monitoring was based on morphological properties observed in soil profiles and laboratory analysis of soil samples collected in the profiles. The soil properties chosen in this study were selected taking in account the main factors limiting plant development in the Mediterranean region like water and nutrients. Thus, was considered to be relevant soil effective thickness, bulk density, clay content and soil organic $\mathrm{C}$, because they have an important role in water storage, nutrient availability and root expansion. Chemical properties as total $\mathrm{N}$, available $\mathrm{P}$ and $\mathrm{K}$, exchangeable bases, cation exchange capacity and $\mathrm{pH}$ are relevant for biological activity and plant nutrition. Soil quality measures such as the ones proposed here can be usefully combined with measurements of soil loss (Sparling et al., 2004). Data on soil loss can be found in Figueiredo et al. (2011). In this work will be addressing the effects of soil erosion on soil properties, using an enrichment ratio (E), where $E$ = nutrient content or other property in eroded sediment / nutrient content or other property in original soil (Gachene et al. 1997). Thus, whenever E $>1$ means that the eroded sediment was enriched in the element analyzed, in relation to original soil, which may indicate the occurrence of natural soil fertility loss by erosion action. Also, in order to identify differences in soil properties between original soil (TSMO) and site preparation operations (SMPC, RCAV, SRVC, RLVC, RCVC and RCLC), was applied the same idea of enrichment ratio $(\mathrm{E})$, but now $\mathrm{E}=$ soil property in each site preparation operations / soil property in original soil. When $E>1$ means that the soil property analyzed was improved with site preparation.

Soil samples collected in soil profiles, were air dried, sieved (mesh size $2 \mathrm{~mm}$ ) and analysed for organic C (WalkleyBlack method), total N (Kjeldahl method), available P and $\mathrm{K}$ ((Egner-Riehm method). Exchangeable bases were determined by atomic adsorption $\left(\mathrm{Ca}^{2+}\right.$ and $\left.\mathrm{Mg}^{2+}\right)$ and by flame emission spectrophotometry $\left(\mathrm{K}^{+}\right.$and $\left.\mathrm{Na}^{+}\right)$. Cation exchange capacity was calculated as the sum of exchangeable bases and exchangeable acidity. Soil $\mathrm{pH}$ was measured in a soil-water suspension (1:2.5 soil-water ratio). Effective soil thickness, defined as the set of layers most explored by plant roots, was measured in each profile during soil profile description. Bulk density was determined in undisturbed samples, weighting oven-dried soil (at $105^{\circ} \mathrm{C}$ ), collected in $100 \mathrm{~cm}^{3}$ cylinders in depths $0-5,5-15$, $15-30$ and $30-60 \mathrm{~cm}$. Particle size analysis was done by pipette method.
Statistical analysis of data comprised one-way ANOVA and multiple comparison of averages (Tukey, 5\%), performed to assess the significance of treatment effects on results. Simple correlation analyses were applied to estimate relationships between soil properties and variables measured in plants.

\section{Results AND Discussion}

Physical soil quality indicators

In slight soil disturbance treatments (SMPC and RCAV), the soil effective thickness (rooting depth) remains very similar to the original soil (TSMO), but in treatments with moderate and intensive site preparation (SRVC, RLVC and RCLC) there are a significant increase ranging from 30 to $40 \mathrm{~cm}$ (Figure 1). The soil effective thickness is a property that varies very little over time and reflects the soil physical conditions ability for plant growth (Wang and Gong 1998, Schoenholtz et al. 2000). Given the climatic characteristics of the study area (high summer water deficit), the soil effective thickness proved to be a property determinant of survival and growth of forest species installed (Figure 2), showing a good correlation at the end of 42 months with survival $\left(r^{2}=0.942\right.$ and 0.745 , respectively for $P M$ and $C S$ species) and with the height and diameter growth for $P M\left(r^{2}=0.859\right.$ and 0.781 , respectively) and CS $\left(\mathrm{r}^{2}=0.919\right.$ and 0.975 , respectively). Moreover, in plots in which soil effective thickness did not exceed $60 \mathrm{~cm}$, the mortality was above 95\% for both species (Fonseca et al., 2011). Also, treatments with moderate and intensive site preparation contributed to decrease bulk density in all depths considered. Bulk density values ranging from 1.44 to $1.76 \mathrm{~g}$ $\mathrm{cm}^{-3}$ in the original soil (TSMO) and 1.33 to $1.39 \mathrm{~g} \mathrm{~cm}^{-3}$ in RCVC treatment, respectively for 0-5 and 30-60 cm depth. The remaining treatments showed values intermediate to these (Figure 3). Furthermore, intensification of site preparation also contributed to the reduction of spatial and vertical bulk density variability (see meaning letters of bars in Figure 3), which favors water and oxygen availability (Schoenholtz et al. 2000) and root development (Logsdon and Karlen 2004). Soil texture classes ranging among loam and sandy-loam (Table 2). However, there are variations in sand, silt and clay fractions, which can lead to differences in pore size and consequently cause differences in aeration conditions and soil water retention (Dexter 2004). In general, there are no significant differences between treatments for the fine earth fraction (sand, silt and clay), but the treatments with furrow hillock surface soil (SRVC, RLVC and RCVC) show an increase in clay content in surface mineral layer $(0-20 \mathrm{~cm})$, showing a reverse trend in the deeper soil layers (20-40 and 40-60 cm), when compared with the original soil (TSMO). Once the young plants are essentially dependent on the moisture content of the surface layers (Fernandes and Fernandes 1998; Kanegae et al. 2000), these higher levels of clay can help increase water retention and nutrients absorption during summer rainfall, with positive impact on plantations' success. 
Figure 1 - Means of soil effective thickness one year after site preparation. For treatments, averages with the same letter are not significantly different $(\mathrm{P}<0.05)$

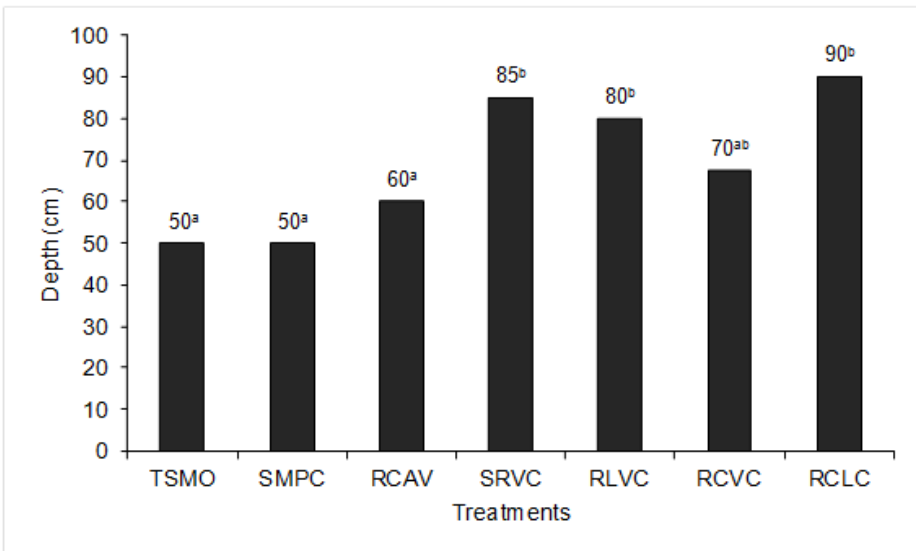

Figure 2 - Relationship of survival and growth in height and diameter of PM (A) and CS (B) species with the soil effective thickness, according to the treatments

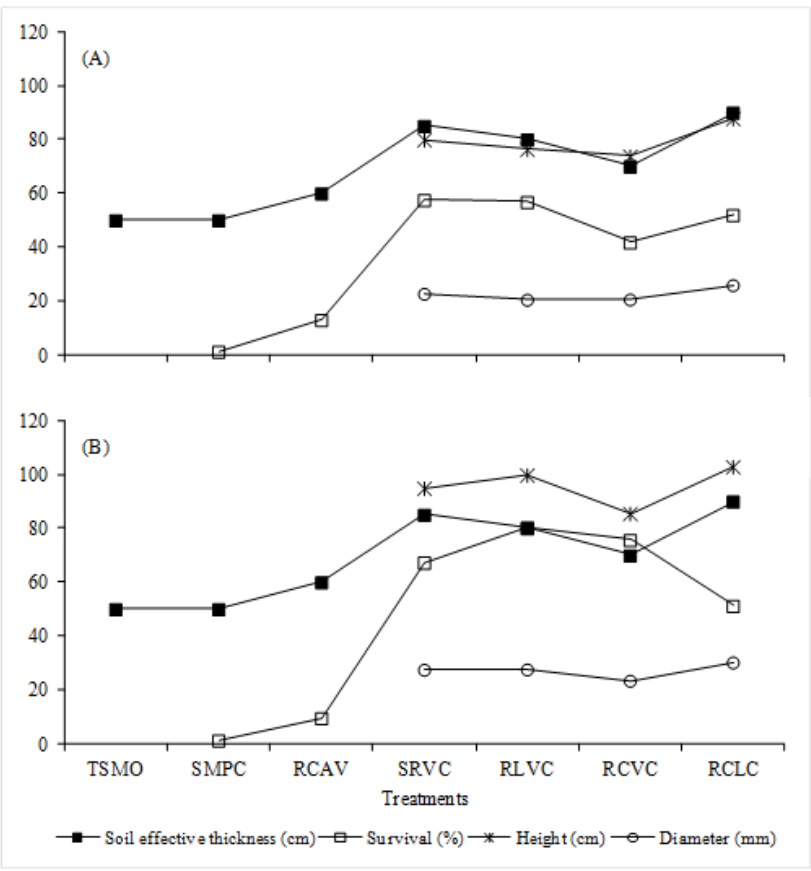

Figure 3 - Soil bulk density ( $\mathrm{g} \mathrm{cm}-3$ ) per treatment and soil depth. The first letter indicates that for the same treatment, means followed by the same letter depths are not significantly different; the second letter indicates that for the same depth, means followed by the same letter treatments are not significantly different $(\mathrm{P}<0.05)$

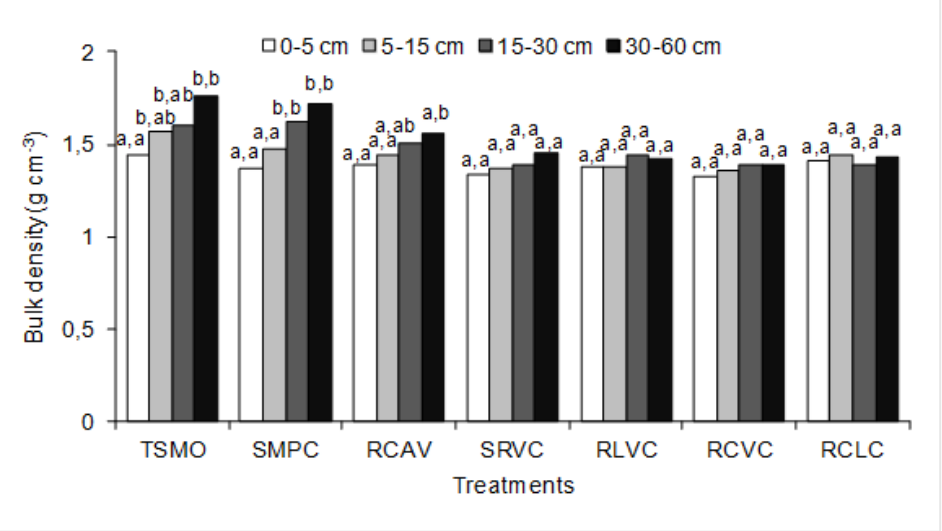


Tabe 2 - Soil particle size distribution under different site preparation techniques (treatments). In the same line, means followed by the same letter are not significantly different $(\mathrm{P}>0.05)$

\begin{tabular}{|c|c|c|c|c|c|c|c|c|}
\hline \multirow[t]{2}{*}{ Soil properties } & \multirow[t]{2}{*}{ Depth $(\mathrm{cm})$} & \multicolumn{7}{|l|}{ Treatments } \\
\hline & & TSMO & SMPC & RCAV & SRVC & RLVC & $\mathrm{RCVC}$ & RCLC \\
\hline \multirow[t]{3}{*}{ Coarse sand (\%) } & $0-20$ & $37.9^{\mathrm{a}}$ & $35.2^{\mathrm{a}}$ & $32.6^{a}$ & $33.1^{\mathrm{a}}$ & $27.7^{\mathrm{a}}$ & $35.0^{\mathrm{a}}$ & $37.6^{\mathrm{a}}$ \\
\hline & $20-40$ & $36.7^{\mathrm{a}}$ & $34.9^{\mathrm{a}}$ & $34.2^{\mathrm{a}}$ & $33.1^{\mathrm{a}}$ & $33.0^{\mathrm{a}}$ & $36.6^{a}$ & $33.1^{\mathrm{a}}$ \\
\hline & $40-60$ & $42.1^{\mathrm{b}}$ & $36.4^{\mathrm{b}}$ & $33.6^{\mathrm{ab}}$ & $22.8^{\mathrm{a}}$ & $30.6^{\mathrm{ab}}$ & $39.8^{\mathrm{b}}$ & $35.6^{\mathrm{b}}$ \\
\hline \multirow[t]{3}{*}{ Fine sand (\%) } & $0-20$ & $33.0^{\mathrm{a}}$ & $32.7^{\mathrm{a}}$ & $33.8^{\mathrm{a}}$ & $28.8^{\mathrm{a}}$ & $34.1^{\mathrm{a}}$ & $26.3^{a}$ & $27.8^{\mathrm{a}}$ \\
\hline & $20-40$ & $29.4^{\mathrm{a}}$ & $26.2^{\mathrm{a}}$ & $32.7^{a}$ & $32.0^{\mathrm{a}}$ & $32.4^{\mathrm{a}}$ & $32.3^{a}$ & $32.7^{\mathrm{a}}$ \\
\hline & $40-60$ & $25.5^{\mathrm{a}}$ & $30.7^{\mathrm{a}}$ & $22.2^{\mathrm{a}}$ & $38.9^{\mathrm{a}}$ & $33.7^{\mathrm{a}}$ & $31.9^{\mathrm{a}}$ & $29.7^{\mathrm{a}}$ \\
\hline \multirow[t]{3}{*}{ Silt (\%) } & $0-20$ & $18.6^{\mathrm{a}}$ & $21.1^{\mathrm{ab}}$ & $20.8^{\mathrm{ab}}$ & $24.2^{\mathrm{ab}}$ & $25.2^{\mathrm{ab}}$ & $27.5^{\mathrm{b}}$ & $25.9^{\mathrm{ab}}$ \\
\hline & $20-40$ & $19.0^{\mathrm{a}}$ & $19.9^{\mathrm{a}}$ & $19.6^{a}$ & $24.6^{\mathrm{a}}$ & $23.5^{\mathrm{a}}$ & $20.8^{\mathrm{a}}$ & $21.4^{\mathrm{a}}$ \\
\hline & $40-60$ & $16,7^{\mathrm{a}}$ & $14.7^{\mathrm{a}}$ & $20.8^{a}$ & $26.1^{\mathrm{a}}$ & $19.3^{\mathrm{a}}$ & $16.7^{\mathrm{a}}$ & $23.3^{\mathrm{a}}$ \\
\hline \multirow[t]{3}{*}{ Clay (\%) } & $0-20$ & $10.6^{\mathrm{ab}}$ & $11.0^{\mathrm{ab}}$ & $12.7^{\mathrm{ab}}$ & $14.0^{\mathrm{b}}$ & $12.9^{\mathrm{ab}}$ & $11.1^{\mathrm{ab}}$ & $8.7^{\mathrm{a}}$ \\
\hline & $20-40$ & $14.9^{\mathrm{a}}$ & $19.1^{\mathrm{a}}$ & $13.5^{\mathrm{a}}$ & $10.3^{\mathrm{a}}$ & $11.2^{\mathrm{a}}$ & $10.3^{a}$ & $12.5^{\mathrm{a}}$ \\
\hline & $40-60$ & $15.7^{\mathrm{ab}}$ & $18.3^{\mathrm{ab}}$ & $23.5^{\mathrm{b}}$ & $12.1^{\mathrm{a}}$ & $16.4^{\mathrm{ab}}$ & $11.6^{\mathrm{a}}$ & $11.4^{\mathrm{a}}$ \\
\hline
\end{tabular}

\section{Chemical soil quality indicators}

When compared with the original soil (TSMO), the treatments with moderate and high soil disturbance (SRVC, RLVC, RCVC and RCLC), contributed to a significant decrease in organic C concentration (59, 48, 35 and 47\% for the SRVC, RLVC, RCVC and RCLC treatments, respectively) and total $\mathrm{N}$ (45, 33, 30 and 44\% for the same treatments, respectively) in surface layer $(0-20 \mathrm{~cm})$ (Table 3 and Figure 4), being the result of the disruption of the balance between formation and mineralization humus processes (Madeira et al. 1989; Islam and Weil 2000; Saviozzi et al. 2001). In the same treatments, C and $\mathrm{N}$ tends to increase in depth, showing significantly higher levels in deeper layer $(40-60 \mathrm{~cm})$, which is associated with the migration of organic matter in the soil profile by the action of tillage. Despite the changes observed in the levels of carbon and nitrogen, Dick et al. (1998) reported that the largest variations in organic matter content occur during the first five years after site preparation, with little variation beyond that period. Available $\mathrm{P}$ values (Figure 5A) range from very low (0-25 mg kg-1) to low (26-50 $\mathrm{mg} \mathrm{kg}^{-1}$ ) (Santos, 1991). These values can be related to phenomena of retention and fixation, tending to increase with depth and tillage intensity, which is very important because Portuguese soils are very poor in this nutrient (Arrobas and Coutinho 2002). However, these concentrations do not necessarily mean that there are deficiencies of phosphorus given the presence of mycorrhizal fungi (commonly observed during root systems observation) to promote plant nutrition, including phosphorus absorption, even if it is in low concentrations in soil (Binkley 1986; Honrubia 1992). In relation to available K (Figure 5B), this shows values considered moderate (51-100 mg kg-1) (Santos 1991). Site preparation techniques influenced positively the potassium availability owing to changes in other factors such as aeration, temperature and moisture content (Sharma et al. 2005), but without a consistent trend. In surface soil layer, sum of exchangeable bases increase, although only significantly in SRVC (Table 3). These values are considered very low (Metson 1956), which is justified by the lithology of the parent material and leaching phenomena. Calcium is the most important basic cation in the soil, contributing around $70 \%$ for the sum exchangeable bases.

Figure 4 - Variation of soil organic carbon (A) and total nitrogen (B) in relation to the original soil (TSMO)

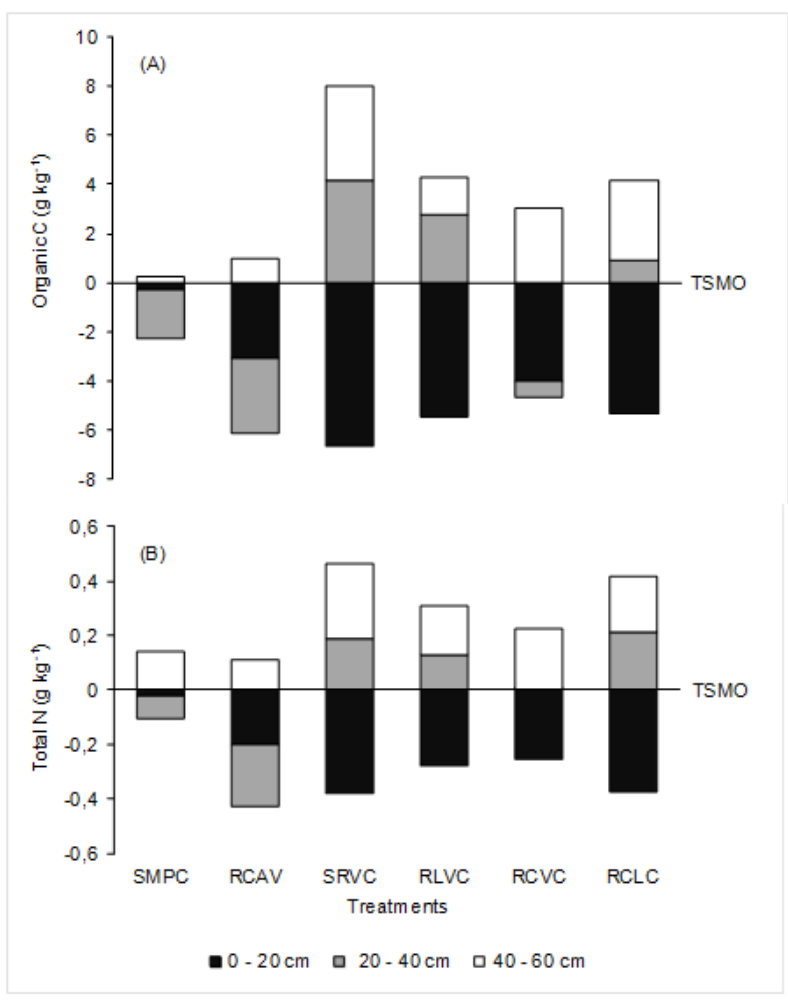


Table 3 - Chemical soil properties under different site preparation techniques (treatments). In the same line, means followed by the same letter are not significantly different $(\mathrm{P}>0.05)$

\begin{tabular}{|c|c|c|c|c|c|c|c|c|}
\hline \multirow[t]{2}{*}{ Soil properties } & \multirow[t]{2}{*}{ Depth $(\mathrm{cm})$} & \multicolumn{7}{|l|}{ Treatments } \\
\hline & & TSMO & SMPC & RCAV & SRVC & RLVC & $\mathrm{RCVC}$ & RCLC \\
\hline \multirow[t]{3}{*}{ Organic $C\left(\mathrm{~g} \mathrm{~kg}^{-1}\right)$} & $0-20$ & $11.4^{\mathrm{b}}$ & $11.1^{\mathrm{b}}$ & $8.3^{\mathrm{ab}}$ & $4.7^{\mathrm{a}}$ & $5.9^{\mathrm{a}}$ & $7.4^{\mathrm{a}}$ & $6.0^{\mathrm{a}}$ \\
\hline & $20-40$ & $6.3^{\mathrm{ab}}$ & $4.3^{\mathrm{ab}}$ & $3.2^{\mathrm{a}}$ & $10.5^{\mathrm{b}}$ & $9.0^{\mathrm{b}}$ & $5.6^{\mathrm{ab}}$ & $7.2^{\mathrm{ab}}$ \\
\hline & $40-60$ & $2.5^{\mathrm{a}}$ & $2.7^{\mathrm{a}}$ & $3.5^{\mathrm{a}}$ & $6.4^{\mathrm{a}}$ & $4.0^{\mathrm{a}}$ & $5.5^{\mathrm{a}}$ & $5.7^{\mathrm{a}}$ \\
\hline \multirow{3}{*}{ Total N $\left(\mathrm{g} \mathrm{kg}^{-1}\right)$} & $0-20$ & $0.85^{\mathrm{b}}$ & $0.82^{\mathrm{b}}$ & $0.65^{\mathrm{ab}}$ & $0.46^{\mathrm{a}}$ & $0.57^{\mathrm{a}}$ & $0.59^{\mathrm{a}}$ & $0.47^{\mathrm{a}}$ \\
\hline & $20-40$ & $0.54^{\mathrm{ab}}$ & $0.46^{\mathrm{ab}}$ & $0.30^{\mathrm{a}}$ & $0.73^{\mathrm{b}}$ & $0.66^{\mathrm{ab}}$ & $0.54^{\mathrm{ab}}$ & $0.75^{\mathrm{b}}$ \\
\hline & $40-60$ & $0.29^{\mathrm{a}}$ & $0.43^{\mathrm{ab}}$ & $0.40^{\mathrm{ab}}$ & $0.57^{\mathrm{b}}$ & $0.47^{\mathrm{ab}}$ & $0.51^{\mathrm{ab}}$ & $0.49^{\mathrm{ab}}$ \\
\hline \multirow[t]{3}{*}{$\mathrm{SEB}\left(\mathrm{cmol} \mathrm{kg}^{-1}\right)$} & $0-20$ & $1.52^{\mathrm{a}}$ & $1.39^{\mathrm{a}}$ & $1.77^{\mathrm{a}}$ & $3.32^{\mathrm{b}}$ & $1.57^{\mathrm{a}}$ & $1.19^{\mathrm{a}}$ & $2.26^{\mathrm{ab}}$ \\
\hline & $20-40$ & $1.71^{\mathrm{a}}$ & $1.67^{\mathrm{a}}$ & $2.02^{\mathrm{ab}}$ & $3.35^{\mathrm{b}}$ & $1.78^{\mathrm{a}}$ & $1.32^{\mathrm{a}}$ & $2.59^{\mathrm{ab}}$ \\
\hline & $40-60$ & $1.81^{\mathrm{a}}$ & $2.82^{\mathrm{ab}}$ & $3.04^{\mathrm{b}}$ & $1.53^{\mathrm{a}}$ & $1.97^{\mathrm{a}}$ & $1.67^{\mathrm{a}}$ & $1.22^{\mathrm{a}}$ \\
\hline \multirow[t]{3}{*}{$\mathrm{CEC}\left(\mathrm{cmol} \mathrm{kg}^{-1}\right)$} & $0-20$ & $3.31^{\mathrm{a}}$ & $3.26^{\mathrm{a}}$ & $3.92^{\mathrm{a}}$ & $6.57^{\mathrm{b}}$ & $3.63^{\mathrm{a}}$ & $3.30^{\mathrm{a}}$ & $4.59^{a}$ \\
\hline & $20-40$ & $4.24^{\mathrm{a}}$ & $4.43^{\mathrm{a}}$ & $4.16^{a}$ & $5.35^{\mathrm{a}}$ & $4.68^{\mathrm{a}}$ & $3.29^{\mathrm{a}}$ & $4.31^{\mathrm{a}}$ \\
\hline & $40-60$ & $5.26^{a}$ & $5.32^{\mathrm{a}}$ & $6.42^{\mathrm{a}}$ & $4.66^{a}$ & $4.30^{\mathrm{a}}$ & $5.34^{a}$ & $4.24^{\mathrm{a}}$ \\
\hline \multirow[t]{3}{*}{$\mathrm{BS}(\% \mathrm{CEC})$} & $0-20$ & $47.1^{a}$ & $42.5^{a}$ & $43.0^{\mathrm{a}}$ & $44.8^{\mathrm{a}}$ & $43.2^{\mathrm{a}}$ & $36.7^{\mathrm{a}}$ & $50.2^{\mathrm{a}}$ \\
\hline & $20-40$ & $42.8^{a}$ & $41.5^{a}$ & $48.9^{a}$ & $48.8^{\mathrm{a}}$ & $38.6^{a}$ & $39.3^{a}$ & $45.2^{\mathrm{a}}$ \\
\hline & $40-60$ & $39.8^{a}$ & $50.6^{\mathrm{a}}$ & $51.4^{\mathrm{a}}$ & $34.5^{\mathrm{a}}$ & $46.3^{a}$ & $36.8^{a}$ & $32.0^{\mathrm{a}}$ \\
\hline \multirow[t]{3}{*}{$\mathrm{pH}\left(\mathrm{H}_{2} \mathrm{O}\right)$} & $0-20$ & $5.1^{\mathrm{a}}$ & $4.9^{\mathrm{a}}$ & $5.1^{\mathrm{a}}$ & $5.0^{\mathrm{a}}$ & $4.9^{\mathrm{a}}$ & $4.8^{\mathrm{a}}$ & $5.0^{\mathrm{a}}$ \\
\hline & $20-40$ & $5.0^{\mathrm{a}}$ & $4.9^{\mathrm{a}}$ & $5.0^{\mathrm{a}}$ & $4.9^{\mathrm{a}}$ & $4.9^{\mathrm{a}}$ & $4.9^{\mathrm{a}}$ & $5.0^{\mathrm{a}}$ \\
\hline & $40-60$ & $5.0^{\mathrm{a}}$ & $4.9^{\mathrm{a}}$ & $5.0^{\mathrm{a}}$ & $4.8^{\mathrm{a}}$ & $5.0^{\mathrm{a}}$ & $5.0^{\mathrm{a}}$ & $4.7^{\mathrm{a}}$ \\
\hline
\end{tabular}

SEB - sum exchange bases; CEC - cation exchange capacity; BS - base saturation

Figure 5 - Available phosphorus (A) and potassium (B) one year after site preparation. For treatments, averages with the same letter are not significantly different $(\mathrm{P}<0.05)$

( A )
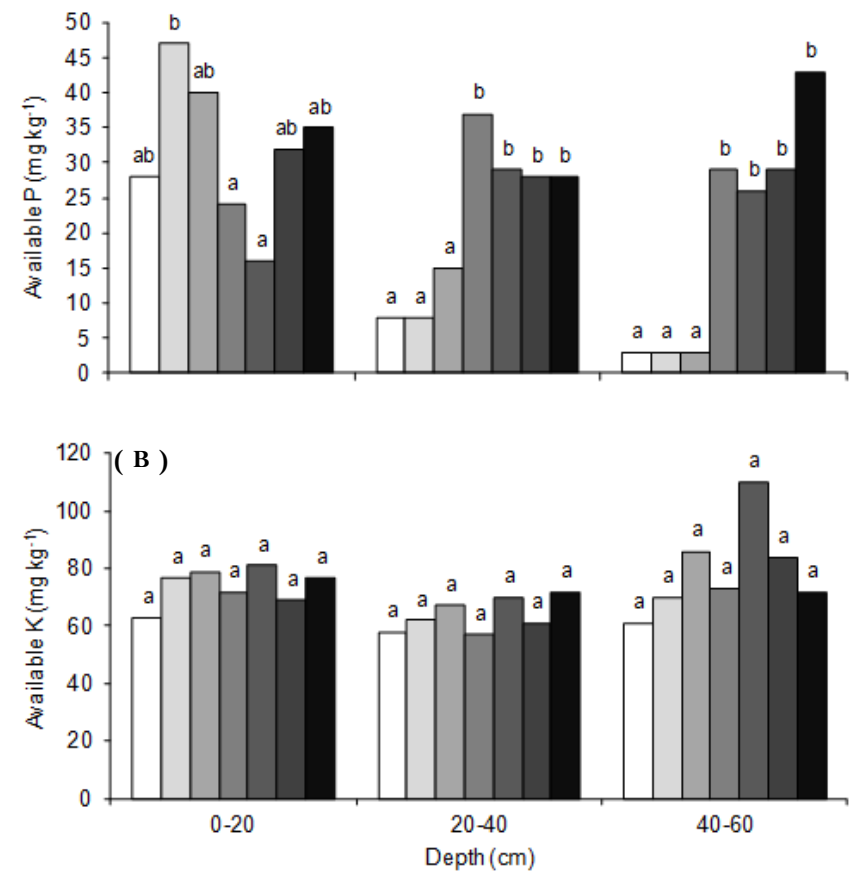

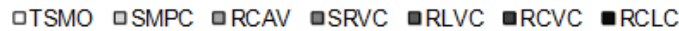


Enrichment of surface soil layer and eroded sediment after site preparation

Values of enrichment ratios (E) for clay, soil organic C, total $\mathrm{N}$, available $\mathrm{P}$ and $\mathrm{K}$, exchange bases $\left(\mathrm{Ca}^{2+}\right.$ and $\left.\mathrm{Mg}^{2+}\right)$, cation exchange capacity (CEC) and $\mathrm{pH}\left(\mathrm{H}_{2} \mathrm{O}\right)$ of the surface soil layer $(0-20 \mathrm{~cm})$ and eroded sediment are depicted in Table 4. Data for RCLC treatment are missing because the high surface ground roughness after site preparation was such that erosion monitoring was discarded.

When compared with original soil, site preparation increased clay content and nutrients availability in soil (usually $\mathrm{E}>1$ ) with the exception of organic $\mathrm{C}$ and total $\mathrm{N}$, as a result, site preparation can have several positive effects on soil quality in Mediterranean region. In eroded sediment E were higher than unity for almost all sediment elements, being particularly high for total $\mathrm{N}$, available $\mathrm{K}$ and $\mathrm{Mg}^{2+}$. Clay content showed $\mathrm{E}<1$, which was unexpected because majority of soils preferentially lose clay particles in eroded sediment. Gachene et al. (1997) obtained similar results. Soil pH E is slightly above unity, which highlights the enrichment of the sediment in exchange bases in relation to original soil. Soil organic $\mathrm{C}$ and total $\mathrm{N}$ losses associated with site preparation techniques and soil erosion could be the major environmental problem in this region and could have adverse effects on physical and chemical soil properties. However, the low sediment production, about $1 \mathrm{t} \mathrm{ha}^{-1} \mathrm{yr}^{-1}$, (Figueiredo et al. 2011) observed during this study showed that the damage to the system by erosion was hardly noticeable.

Table 4 - Enrichment ratios (E) of surface soil layer $(0-20 \mathrm{~cm})$ and eroded sediment according to the treatments t. In the same line, means followed by the same letter are not significantly different $(\mathrm{P}>0.05)$

\begin{tabular}{|c|c|c|c|c|c|}
\hline \multirow[t]{2}{*}{ Parameter } & \multicolumn{5}{|c|}{ Treatments } \\
\hline & SMPC & RCAV & SRVC & RLVC & $\mathrm{RCVC}$ \\
\hline \multicolumn{6}{|c|}{ Surface soil layer $(0-20 \mathrm{~cm})($ TSMO values equal 1$)$} \\
\hline Clay (\%) & $1.13 \mathrm{a}$ & $1.31 \mathrm{a}$ & $1.44 \mathrm{a}$ & $1.33 \mathrm{a}$ & $1.25 \mathrm{a}$ \\
\hline Organic C $\left(\mathrm{g} \mathrm{kg}^{-1}\right)$ & $0.98 \mathrm{a}$ & $0.73 a$ & $0.41 \mathrm{a}$ & $0.52 \mathrm{a}$ & $0.65 a$ \\
\hline Total N $\left(\mathrm{g} \mathrm{kg}^{-1}\right)$ & $0.97 \mathrm{a}$ & $0.76 a$ & $0.55 \mathrm{a}$ & $0.67 \mathrm{a}$ & $0.70 \mathrm{a}$ \\
\hline Available P $\left(\mathrm{mg} \mathrm{kg}^{-1}\right)$ & $1.68 \mathrm{~b}$ & $1.43 \mathrm{~b}$ & $0.86 \mathrm{a}$ & $0.57 \mathrm{a}$ & $1.14 \mathrm{a}$ \\
\hline Available $\mathrm{K}\left(\mathrm{mg} \mathrm{kg}^{-1}\right)$ & $1.22 \mathrm{a}$ & $1.25 \mathrm{a}$ & $1.14 \mathrm{a}$ & $1.29 \mathrm{a}$ & $1.10 \mathrm{a}$ \\
\hline $\mathrm{Ca}^{2+}\left(\mathrm{cmol} \mathrm{kg}^{-1}\right)$ & $0.95 \mathrm{a}$ & $1.25 \mathrm{a}$ & $2.21 \mathrm{~b}$ & $1.10 \mathrm{a}$ & $0.84 a$ \\
\hline $\mathrm{Mg}^{2+}\left(\mathrm{cmol} \mathrm{kg}^{-1}\right)$ & $0.75 a$ & $1.13 \mathrm{a}$ & $2.84 \mathrm{~b}$ & $0.94 a$ & $0.56 a$ \\
\hline $\mathrm{CEC}\left(\mathrm{cmol} \mathrm{kg}^{-1}\right)$ & $0.98 \mathrm{a}$ & $1.18 \mathrm{a}$ & $1.98 \mathrm{~b}$ & $1.10 \mathrm{a}$ & $1.00 \mathrm{a}$ \\
\hline $\mathrm{pH}\left(\mathrm{H}_{2} \mathrm{O}\right)$ & $0.96 a$ & $1.00 \mathrm{a}$ & $0.98 \mathrm{a}$ & $0.96 \mathrm{a}$ & $0.94 a$ \\
\hline
\end{tabular}

Eroded sediment (Treatment surface soil values equal 1)

\begin{tabular}{llllll} 
Clay $(\%)$ & $0.60 \mathrm{a}$ & $0.62 \mathrm{a}$ & $0.53 \mathrm{a}$ & $0.67 \mathrm{a}$ & $0.84 \mathrm{a}$ \\
Organic C $\left(\mathrm{g} \mathrm{kg}^{-1}\right)$ & $1.50 \mathrm{~b}$ & $1.05 \mathrm{a}$ & $1.40 \mathrm{~b}$ & $0.91 \mathrm{a}$ & $1.46 \mathrm{~b}$ \\
Total N $\left(\mathrm{g} \mathrm{kg}^{-1}\right)$ & $2.02 \mathrm{~b}$ & $1.35 \mathrm{a}$ & $2.29 \mathrm{~b}$ & $1.42 \mathrm{a}$ & $1.14 \mathrm{a}$ \\
Available P $\left(\mathrm{mg} \mathrm{kg}^{-1}\right)$ & $0.82 \mathrm{a}$ & $0.48 \mathrm{a}$ & $0.56 \mathrm{a}$ & $0.64 \mathrm{a}$ & $0.73 \mathrm{a}$ \\
Available K $\left(\mathrm{mg} \mathrm{kg}^{-1}\right)$ & $1.57 \mathrm{~b}$ & $0.96 \mathrm{a}$ & $1.24 \mathrm{a}$ & $1.68 \mathrm{~b}$ & $1.57 \mathrm{~b}$ \\
$\mathrm{Ca}^{2+}\left(\mathrm{cmol} \mathrm{kg}^{-1}\right)$ & $1.43 \mathrm{~b}$ & $0.96 \mathrm{a}$ & $1.11 \mathrm{a}$ & $0.82 \mathrm{a}$ & $1.05 \mathrm{a}$ \\
$\mathrm{Mg}^{2+}\left(\mathrm{cmol} \mathrm{kg}^{-1}\right)$ & $2.20 \mathrm{~b}$ & $1.02 \mathrm{a}$ & $1.55 \mathrm{~b}$ & $1.69 \mathrm{~b}$ & $1.11 \mathrm{a}$ \\
$\mathrm{CEC}\left(\mathrm{cmol} \mathrm{kg}^{-1}\right)$ & $0.95 \mathrm{a}$ & $0.65 \mathrm{a}$ & $0.75 \mathrm{a}$ & $0.77 \mathrm{a}$ & $0.73 \mathrm{a}$ \\
$\mathrm{pH}\left(\mathrm{H}_{2} \mathrm{O}\right)$ & $1.06 \mathrm{a}$ & $1.06 \mathrm{a}$ & $1.05 \mathrm{a}$ & $1.07 \mathrm{a}$ & $1.04 \mathrm{a}$ \\
\hline
\end{tabular}

CEC - cation exchange capacity

\section{Conclusions}

The site preparation techniques applied to install a mixed forest stand in a Mediterranean region, as reported in this paper, contributed to the increase of soil effective thickness and decreased of soil bulk density. In slight soil disturbance treatments (SMPC and RCAV), the tillage effects are not so evident, approaching the characteristics of these soils to the original situation (TSMO), resulting in high mortality of forest species planted, so they are not recommended for the region under study. In treatments with moderate disturbance (SRVC and RLVC), despite the significant reduction of the carbon and nitrogen, contributed to an overall improvement of soil quality indicators (clay, soil effective thickness, bulk density, available $\mathrm{P}$ and $\mathrm{K}$, etc), as well as, to the highest rates of survival and a good height and diameter growth 42 months 
after stand installation. Treatments with the highest intensity of site preparation operations (RCVC, RCLC), associated with rising production costs and possible worsening of environmental impacts, did not compensate these drawbacks with improvements in soil properties and plantations' success. Sediment loss due to site preparation was low (about $1 \mathrm{t} \mathrm{ha}^{-1}$ $\mathrm{yr}^{-1}$ ), consequently the soil fertility loss associated with soil erosion was of little relevance. Thus, in the region under study, the treatments SRVC and RLVC proved to be more sustainable for forest stands installation. Finally, it is important to note that the type of site preparation technique is extremely important in soils from areas where annual rainfall distribution shows a misfit with the growing season, as occurs in the Mediterranean region.

\section{ACKNOWLedgments}

The authors wish to thank the Program AGRO measure 8.1, project Agro-156, which financially supported this study, the Regional Forestry Services that took charge of site preparation mechanical operations and Mr. João Xavier, the owner of the experimental area, for his agreement on the establishment of the experiment.

\section{REFERENCES}

Agroconsultores and Coba 1991. Carta dos Solos do Nordeste de Portugal. UTAD, Vila Real.

Alcázar J, Rothwell RL andWoodard PM. 2002. Soil disturbance and the potential for erosion after mechanical site preparation. Northern Journal of Applied Forestry, 19 (1): 5-13.

Arrobas M and Coutinho J. 2002. Phosphorus characterization in soils from Portugal. Revista de Ciências Agrárias, XXV: 109-122.

Binkley D. 1986. Forest Nutrition Management. John Wiley and Sons, New York.

Dexter AR. 2004. Soil physical quality. Part I. Theory, effects of soil texture, density, and organic matter, and effects on root growth. Geoderma, 120: 201-214.

Dick WA, Blevins RL, Frye WW, Peters SE, Christenson DR, Pierce FJ and Vitosh ML. 1998. Impacts of agricultural management practices on $\mathrm{C}$ sequestration in forest-derived soils of the eastern Corn Belt. Soil and Tillage Research, 47: 235-244.

Doran JW and Parkin TB. 1994. Defining and assessing soil quality. p. 3-21. In JW Doran, DC Coleman, DF Bezdicek, BA Stewart (eds.) Defining soil quality for a sustainable environment. SSSA Special Publication number 35. Soil Science Society of America, Madison, WI.

FAO/UNESCO 1988. Soil Map of the World, Revised Legend. Amended 4th Draft. FAO, Roma.

Fernandes JAP and Fernandes HMF. 1998. Ensaio de diferentes graus de mobilização em plantações de Pinus pinaster Aiton.

\section{Revista Florestal XI (2): 56-62.}

Figueiredo T, Fonseca F and Martins, A. 2011. Soil loss and runoff in young forest stands as affected by site preparation technique: a study in NE Portugal. European Journal of Forest Research, 131: 1747-1760.

Fonseca F, FigueiredoT and Martins A. 2011. Survival and early growth of mixed forest stands installed in a Mediterranean Region: Effects of site preparation intensity. Forest Ecology and Management, 262: 1905-1912.

Fonseca F., 2005. Técnicas de preparação do terreno em sistemas florestais: Implicações no solo e no comportamento das plantas. PhD Dissertation, Universidade de Trás-os-Montes e Alto Douro, Vila Real, Portugal.

Gachene, C.K.K., Jarvis, N.J., Linner, H., Mbuvi, J.P., 1997. Soil erosion effects on soil properties in a highland area of central Kenya. Soil Science Society of America Journal 61, 559-564.

Honrubia M, Torres P, Díaz G and Cano A. 1992. Manual para micorrizar plantas en viveros forestales. Ministerio de Agricultura, Peca y Alimentacion. ICONA.

Imaz MJ, Virto I, Bescansa P, Enrique A, Fernandez-Ugalde $O$ and Karlen DL. 2010. Soil quality indicator response to tillage and residue management on semi-arid Mediterranean cropland. Soil and Tillage Research, 107: 17-25.

INMG 1991. Normais Climatológicas da Região de "Trás-osMontes e Alto Douro" e "Beira Interior" Correspondentes a 1951-1980. Fascículo XLIX, Volume 3, 3ª Região, Lisboa.

Islam KR and Weil RR. 2000. Land use effects on soil quality in a tropical forest ecosystem of Bangladesh. Agriculture, Ecosystems and Environment, 79: 9-16.

Kanegae MF, Braz V and Franco AC. 2000. Efeitos da seca sazonal e disponibilidade de luz na sobrevivência e crescimento de Bowdichia virgilioides em duas fitofisionomias típicas dos cerrados do Brasil Central. Revta brasil. Bot. 23 (4): 459 468 .

Lal R. 1990. Soil erosion and land degradation: The global risks. pp. 129-172. In R Lal, BA Stewart (eds.) Soil Degradation. New York, Springer-Verlag.

Logsdon SD and Karlen DL. 2004. Bulk density as a soil quality indicator during conversion to no-tillage. Soil and Tillage Research, 78: 143-149.

Lucci S and Della Lena S. 1994. Effect of different site preparation techniques on runoff and erosion in plantation forestry. p. 379-386. In RJ Rickson (ed.) Conserving Soil Resources. CAB International, Wallingford, UK.

Madeira MAV, Melo GF, Alexandre CA and Steen E. 1989. Effects of deep ploughing and superficial disc harrowing on physical and chemical soil properties and biomass in a new plantation of Eucalyptus globulus. Soil and Tillage Research, 14: 163-175.

Metson AJ. 1956. Methods of chemical analysis for survey 
samples. Soil Bureau Bol. n'12. New Zealand Dept. Scient. Ind. Research.

Piatek KB, Harrington CA and Debell DS. 2003. Site preparation effects on 20 year survival and growth of Douglasfir (Pseudotsuga menziesii) and on selected soil properties. Western Journal of Applied Forestry, 18 (1): 44-51.

Querejeta JI, Roldán A, Albadalejo J and Castilllo V. 2001. Soil Water availability improved by site preparation in a Pinus halepensis afforestation under semiarid climate. Forest Ecology and Managment, 149: 115-128.

Santo, Q. 1991. Fertilização - Fundamentos da utilização dos adubos e correctivos. Publicações Europa América, Mem Martins.

Saviozzi A, Levi-Minzi R, Cardelli R and Riffaldi R. 2001. A comparison of soil quality in adjacent cultivated, forest and native grassland soils. Plant and Soil, 233: 251-259.
Schoenholtz SH, Van Miegroet H and Burger JA. 2000. A review chemical and physical properties as indicators of forest soil quality: challenges and opportunities. p. 335-356. In JR Boyle and RF Powers (ed.) Forest soils and ecosystems sustainability. Elsevier, New York.

Sharma KL, Mandal UK, Srinivas K, Vittal KPR, Mandal B, Grace JK and Ramesh V. 2005. Long-term soil management effects on crop yields and soil quality in a dryland Alfisol. Soil and Tillage Research, 83: 246-259.

Sparling GP, Schipper LA, Bettjeman W and Hill R. 2004. Soil quality monitoring in New Zealand: practical lessons from a 6-year trial. Agriculture, Ecosystems and Environment, 104: 523-534.

Wang X and Gong Z. 1998. Assessment and analysis of soil quality changes after eleven years of reclamation in subtropical China. Geoderma, 81: 339-355. 